This item was submitted to Loughborough's Research Repository by the author.

Items in Figshare are protected by copyright, with all rights reserved, unless otherwise indicated.

\title{
Alpine landslide risk scenario: run-out modelling using a 3D approach
}

\section{PLEASE CITE THE PUBLISHED VERSION}

http://dx.doi.org/10.3301/ROL.2017.03

\section{PUBLISHER}

(c) Italian Geological Society

\section{VERSION}

AM (Accepted Manuscript)

\section{PUBLISHER STATEMENT}

This work is made available according to the conditions of the Creative Commons Attribution-NonCommercialNoDerivatives 4.0 International (CC BY-NC-ND 4.0) licence. Full details of this licence are available at: https://creativecommons.org/licenses/by-nc-nd/4.0/

\section{LICENCE}

CC BY-NC-ND 4.0

\section{REPOSITORY RECORD}

Codeglia, Daniela, Neil Dixon, Giulia Bossi, and Gianluca Marcato. 2019. "Alpine Landslide Risk Scenario: Run-out Modelling Using a 3D Approach". figshare. https://hdl.handle.net/2134/24682. 


\title{
Alpine landslide risk scenario: run-out modelling using a 3D approach
}

\author{
Codeglia D. $\left({ }^{(a}\right)$, Dixon N. $\left({ }^{a}\right)$, Bossi G. $\left({ }^{b}\right)$ \& Marcato G. $\left({ }^{b}\right)$
}

(a) School of Civil and Building Engineering, Loughborough University, Loughborough, LE113TU, United Kingdom.

(b) IRPI-CNR Research Institute for Hydro-Geological Hazard Protection, National Research Council of Italy, C.so Stati Uniti 4, 35127 Padua, Italy. E-mail: giulia.bossi@irpi.cnr.it

\begin{abstract}
Rockslides of considerable volume developing on the flanks of narrow alpine valleys represent a significant hazard for the potential of river damming and consequent sudden discharge of water.

A limestone rock mass of about $650,000 \mathrm{~m}^{3}$ endangers a portion of the upper course of Tagliamento River valley in north-eastern Italy. This section of the valley is prone to detachment of rock landslides due to its structural setting and it has a history of landslide damming: in the literature two huge events are widely documented and a third event is identified and described in this paper. The ancient detachment crown and the corresponding deposit can be observed in the portion of slope adjacent to the unstable rock mass.

This paper deals with the run-out model of the unstable rock mass using a Smoothed Particles Hydrodynamics (SPH) model implemented in the DAN3D code. In order to select the appropriate material parameters, the ancient rockslide was back-analysed Subsequently, the parameters were applied to the present unstable portion of the slope to determine the location and dimensions of the deposit that could be formed.

It is demonstrated that the deposit has the potential to create a natural dam across the Tagliamento River that would form a $500,000 \mathrm{~m}^{3}$ lake. Although the lake will have limited dimensions, this would represent a very high risk for the downstream villages and infrastructures in case of a sudden collapse of the natural dam.
\end{abstract}

KEY WORDS: back-analysis, landslide dam, rock slide, run-out model.

\section{INTRODUCTION}

Landslide travel-distance analysis is an essential tool in landslide risk assessment and risk management when largescale phenomena that are difficult to mitigate or prevent are expected.

In narrow Alpine valleys it is also extremely important to consider that the collapsed material could cause valley damming when considerable volumes are likely to be mobilized. Valley damming represents a considerable threat for the populations living downstream for the potential of dam outburst due to the pressure imposed by the impounded water on the natural dam and the consequent water waves that could wipe out the river track (Costa \& Schuster, 1987).

The main constraints of a run-out analysis are connected to the correct selection of rheology parameters of the material being simulated; to date the best approach is considered to be the back-analysis of similar phenomena. For travel distances that are relatively short, also the travel path and the distribution of the material at the source have a considerable impact on the simulation results. This can be challenging when either the preor post-event terrain models are not available and the models have to be artificially built. This is the case when the simulated phenomenon has not yet occurred or an ancient landslide is being analysed (Bossi et al., 2013).

This paper deals with the numerical modelling of the runout of a potential rockslide of about $650,000 \mathrm{~m}^{3}$ (Landslide B) in north-eastern Italy to evaluate the hazard of interference of the deposit with the Tagliamento River, and hence to evaluate the potential associated with the possible sudden discharge of water due to natural dam outburst. To be able to use realistic parameters in the simulation, a landslide that involved the same rock formations occurred on the adjacent portion of slope (Landslide A) was back-analysed.

\section{GEOMORPHOLOGY AND GEOLOGY}

Passo della Morte is an area located on the left flank of the Tagliamento River Valley (Fig.1) to the east of Forni di Sotto, Udine, northern Italy [46.3978 N, $12.7026 \mathrm{E}]$. This area is affected by several hill-slope processes, characterized by a range of typologies and different states of activity (Marcato, 2006; Sinigardi et al., 2015). These phenomena are mainly caused by debuttressing due to a melting glacier, which occupied the valley until 10,000 years ago and reached the maximum thickness of 700-800 $\mathrm{m}$ during the Last Glacial Maximum about 25,000 years ago (Gortani, 1959).

The upper Tagliamento River valley, in the area of Passo della Morte, is characterized by sedimentary rock formations pushed to a near-vertical aspect by thrusts occurred during the Alpine orogeny. The structural setting predisposes the rocks to slide along planes of weakness which could be bedding strata or the plane between two different lithologies.

The valley in this section is particularly narrow, thus collapses of large volumes of rock represent a considerable 
threat.

Landslides that caused damming of the Tagliamento river bed in the past are found in the literature. Martinis (1985) described a rockslide occurred during the last post-glacial era-radiocarbon dating on plant remains found in the deposit confirmed an age of about 10,000 years Before Present (BP). The rockslide of about $50,000,000 \mathrm{~m}^{3}$ generated a barrier lake about $6.5 \mathrm{~km}$ long that lasted for 100 years, as assessed by analysing the clay deposits found in the area (Martinis, 1985). The post-glacial deposit is visible on the right flank of the valley opposite to the Passo della Morte (part of this deposit is included in the cross-sections in Fig.2).

Further downstream, a village called Borta was buried in the year 1692 by a mass of about $30,000,000 \mathrm{~m}^{3}$ detached from the slope. The collapsed rock mass formed a water basin of about 60,000,000 $\mathrm{m}^{3}$ (Cavallin \& Martinis, 1974), which flooded the downstream towns and villages following progressive failure of the barrier as reported by authors of the time.

In addition to these two documented cases, a third ancient rockslide was recognised in the area of Passo della Morte and a potential rockslide was identified on the portion of slope next to it (Codeglia, 2011). In Figure 1 a photograph of the area shows the ancient rock slide deposit (solid line) and corresponding detachment crown, named Landslide A. On the slope it is possible to observe two limestone outcrops; both show precarious structural settings but the one to the left is of considerable concern because of its volume and hence the potential to create a valley barrier in case of failure (Codeglia, 2013). The outcrop to the right has a much smaller volume and therefore it is not considered a threat for valley damming.

In the Passo della Morte area the outcropping formations are massive dolomite (Dolomia dello Schlern - Ladinian), which constitutes the bedrock, and some strips of limestone (Calcari scuri stratificati - Carnian) which steeply lies on the dolomite. Dolomite and limestone sit on top of silty-clays (Argille siltose varicolori - Middle Carnian) and gypsum (Gypsum - Upper Carnian) which are present at the base of the slope.

The "Linea di Sauris", a regional overthrust fault, is responsible for placing the dolomite and limestone on top of more recent formations. The thrust fault runs along the Tagliamento River bed to the west and elevates its position up the slope in the Passo della Morte area (Fig.1). The overthrust brings the Upper Ladinic - Carnian limestone and dolomite over the successive silty clay and gypsum facies formed during the Upper Carnian.

\section{LANDSLIDE A}

The deposit is visible at the base of the slope. A thorough geomorphological survey revealed that the phenomenon was probably initiated by erosion at the toe of the slope operated by the Tagliamento River. The hypothesis is that originally the river used to meander towards the north flank of the valley, progressively eroding the base of the slope in correspondence of rocks (silty-clay) that were highly stressed and crushed due to the "Linea di Sauris" overthrust fault (Fig.2a). When the shear stress overcame the available strength, the limestone above slid along the bedding planes leaving the bare dolomite on the slope (Fig.2b). The falling rock mass crushed into blocks of dimensions from few centimeter up to a meter and invaded the valley probably forming a dam of small dimensions across the Tagliamento River. From geomorphological evaluations it is supposed that the barrier could have been about $20 \mathrm{~m}$ high.

After the event, the river inverted the direction of the meander towards the southern flank to flow around the toe of the deposit, removing part of the collapsed material.

Considering geomorphological evidences and the lack of historical reports, it is estimated that Landslide A occurred between 2000 and 1000 years BP.

\section{LANDSLIDE B}

This is a potential rockslide similar to Landslide A. Explorative boring revealed that in this area the limestone reaches the river bed (i.e. no silty-clay is found on this section of the slope), which is compatible with the hypothesis that the "Linea di Sauris" position is lower in correspondence with this part of the slope. The limestone is therefore wedged at the base of the slope, which justifies why this portion did not collapse along with the adjacent event (Landslide A), requiring a shear zone to develop within the steep limestone for the collapse to be initiated. Signs of stress were found in the outcrops at about $670 \mathrm{~m}$ above sea level, which is about $50 \mathrm{~m}$ above the river bed, and confirmed by the explorative borehole that was drilled between 720-620 $\mathrm{m}$ a.s.1.; hence this is considered to be the possible base detachment level. At its back the unstable mass is limited by the plane that ideally separates limestone from the dolomite, which was a critical feature also for Landslide A described above.

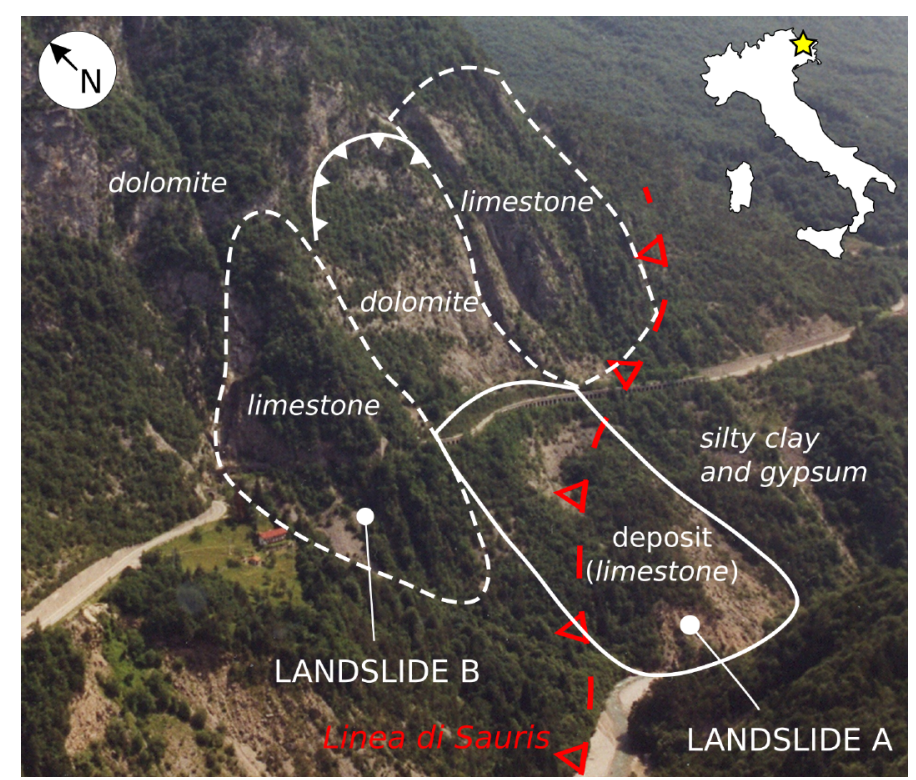

Fig. 1 - Photograph of Passo della Morte (Italy) taken towards north-east, along the Tagliamento River valley. The main geological and geomorphological characteristics are indicated in the figure along with the ancient rockslide (Landslide A) and the potential rockslide (Landslide B). 

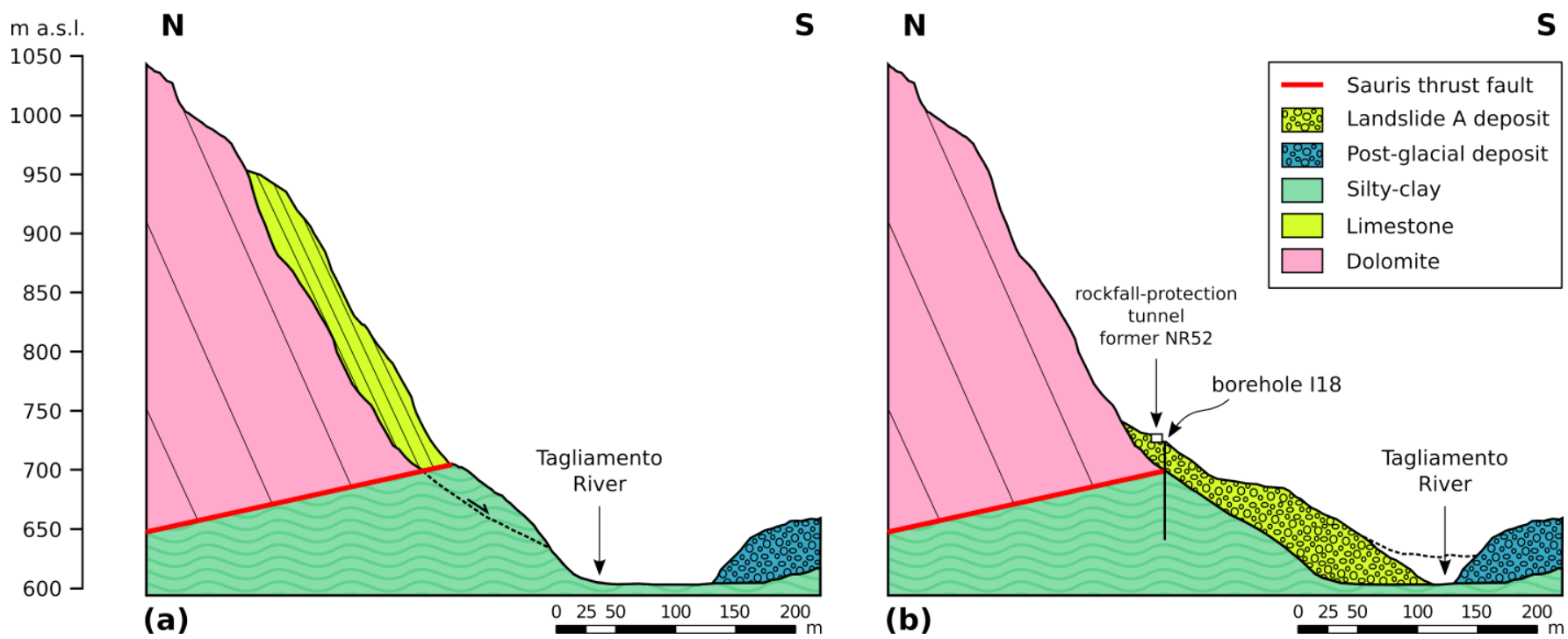

Fig. 2 - North-South cross section along Landslide A. (a) Reconstructed scenario pre-landslide; the river eroded the stressed silty-clay determining the failure of the slope base. (b) Landslide A deposit as it appears today. Borehole I18 confirms the presence of collapsed limestone in the first $21 \mathrm{~m}$ and stressed siltyclay ("Argille siltose varicolori") until the borehole bottom at $-80 \mathrm{~m}$. The dashed line represents how high the barrier could have been just after the collapse.

On the basis of these observations the 3D topography terrain model used in the run-out simulation was later defined.

\section{MODELLING}

The 3D simulation was performed with the DAN3D software (Hungr \& McDougall, 2009; VV.AA., 2010) which is a meshless Smoothed Particle Hydrodynamics code that uses an integrated two-dimensional Lagrangian solution. The rock mass is discretized in numerous particles that flow on a $3 \mathrm{D}$ topography on the basis of a selected rheology.

The input parameters required by the program were a source elevation file, which describes the distribution of the material source; a path topography file, which describes the path along which the particles move, and the material type (rheology parameters).

Frictional rheology was chosen for the simulation as this is the most suitable for dry flows among the rheology types available in the program. The frictional rheology required three parameters: the material unit weight, which was assumed equal to $26 \mathrm{kN} / \mathrm{m}^{3}$ as obtained from laboratory tests on rock specimens; the internal friction angle (i.e. friction angle within the moving mass, among the rock particles) set at $35^{\circ}$, which is indicated as the appropriate value for dry fragmented rock in the manual; and the basal friction angle acting at the interface between the moving mass and the path surface, which was calibrated through a best-fit back-analysis of Landslide A.

\section{BACK ANALYSIS OF LANDSLIDE A}

In order to obtain the material source file, the shape of the limestone slab as it would have appeared prior to failure was reconstructed in 3D. A Digital Terrain Model (DTM) obtained from helicopter LiDAR survey was used as the base. Considerations about geomorphological evidences, orientation of the joints and the internal friction angle of the rock allowed the reconstruction of the missing mass.

The path file was obtained starting from the DTM as well. The deposit was subtracted with the aid of planes placed against morphologies that presumably were not involved in the event and limiting the base of the deposit at the present river bed elevation. The volume of the detached rock mass was estimated to be $750,000 \mathrm{~m}^{3}$.

The model was run several times changing the basal friction angle parameter; the best fit between the real deposit and the simulated one was obtained with an basal friction angle of $33^{\circ}$ (Fig.3a), taking also into consideration that the real deposits have been eroded by the river over time.

\section{RISK SCENARIO LANDSLIDE B}

The basal friction angle obtained from the back-analysis of Landslide A was used in the run-out model of Landslide B. For the risk scenario simulation it was crucial to identify the most likely detachment surfaces in order to build realistic source and path files. Starting from the geomorphological observations and the structural aspect of the bedding planes and other joint sets, the unstable rock mass was isolated by three planes and subtracted from the DEM to create the path and source files. The volume obtained from this configuration is $650,000 \mathrm{~m}^{3}$ of rock that could detach from the slope.

The simulation result (Fig.3b) shows that the deposit would mainly fill a stream channel to the left of the source but it can also reach the river bed and create a natural barrier of about 15 $\mathrm{m}$ in height and $200 \mathrm{~m}$ in length. The simulation does not consider the volume increase of about $30 \%$ due to the void volume increase that normally happens when a rock mass is fragmented. Therefore, the dimensions of the natural dam could likely be bigger, both in height and in length.

The area at the back of the dam obtained with the simulation was flooded to obtain the dimensions of the possible lake, which would have a volume of about $500,000 \mathrm{~m}^{3}$. 

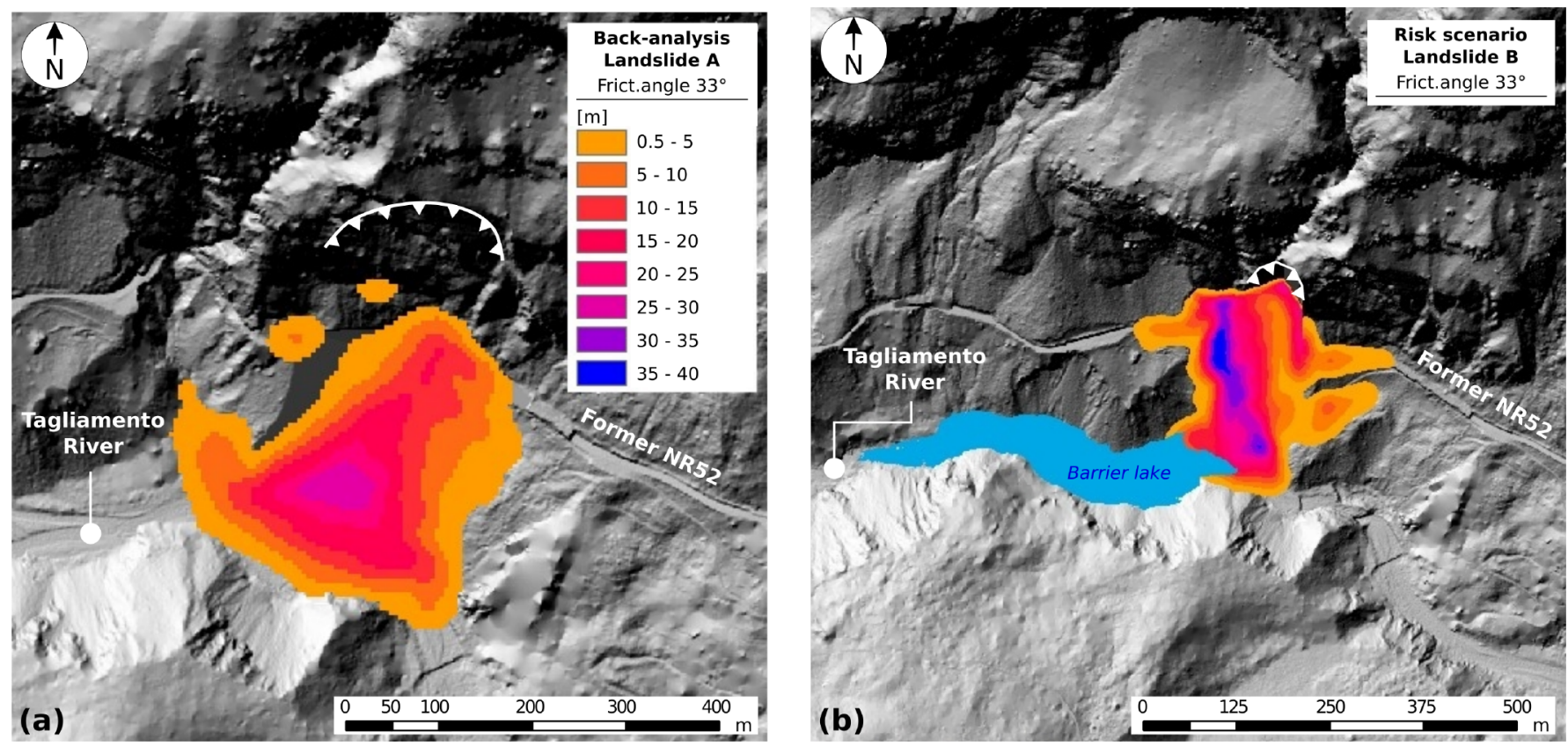

Fig. 3 - Simulation results. (a) Landslide A simulated deposit which best reproduces the actual deposit. (b) Landslide B simulation obtained with the best-fit back-analysed basal friction angle $\left(33^{\circ}\right)$ from Landslide A. The dam is about $15 \mathrm{~m}$ high. The barrier lake that results from flooding the area behind the simulated natural dam (using ArcGis 10.2) is about $500 \mathrm{~m}$ long and contains $500,000 \mathrm{~m}^{3}$ of water.

\section{SUMMARY}

The purpose of this study was to evaluate the possibility of valley damming and dimension of the impoundment that could be generated by the collapse of a $650,000 \mathrm{~m}^{3}$ portion of slope along the Tagliamento River valley in north-eastern Italy.

A run-out analysis using a SPH model was used to evaluate the potential for valley damming. The simulation parameters (basal friction angle) calibration was performed through backanalysis of a similar phenomenon that affected the adjacent portion of slope (Landslide A) and developed in the same rock formations. The basal friction angle selected $\left(33^{\circ}\right)$ was the one that gave the best fit between the real deposit and the simulated one in terms of thickness and distribution.

The analysis conducted on the unstable rock mass (Landslide B) confirms that the mass can cause a natural barrier of at least $15 \mathrm{~m}$. If the dam was filled at its back, it would generate a lake of at least $500,000 \mathrm{~m}^{3}$.

The limitations and assumptions for this type of analysis concern mainly the volumes involved. Firstly, particular attention should be given to the construction of the source and path files, in particular when relatively short run-out is expected as these can affect the volumes involved and the direction of movement of the mass. A thorough geomorphological analysis is essential to be able to locate the critical elements and correctly orient the artificial planes that describe the detachment surface in the path files. Secondly, the code used for the simulation does not consider volume increase which inevitably reflects on slightly underestimated results.

\section{ACKNOWLEDGMENTS}

Laboratory tests on rock specimens were funded by Fondazione CARIPARO (Italy) through the SMILAND project.

\section{REFERENCES}

Bossi G., Frigerio S., Mantovani M., Schenato L., Pasuto A. \& Marcato G. (2013) - Hazard assessment of a potential rock avalanche in South Tyrol, Italy: 3D modeling and risk scenarios. Ital. J. Eng. Geol. Environ. 6, 221-227.

Cavallin A. \& Martinis B. (1974) - Studio geologico della grande frana di Borta (Ampezzo). Alto 58, 297-319.

Codeglia D. (2011) - Analisi geomeccanica e predisposizione di un sistema di monitoraggio lungo la galleria del Passo della Morte. Unpublished dissertation. University of Trieste, Italy.

Codeglia D. (2013) - Analisi numerica tridimensionale tramite modello SPH della frana di Passo della Morte (UD). Unpublished Master's thesis. University of Bologna, Italy.

Costa J. \& Schuster R. (1987) - The formation and failure of natural dams. 87-392.

Gortani M. (1959) - Carta della glaciazione würmiana in Friuli. Atti Acc. Sc. Ist. di Bol. IX, 1-11.

Hungr O. \& McDougall S. (2009) - Two numerical models for landslide dynamic analysis. Comput. Geosci. 35, 978-992.

Marcato G. (2006) - Valutazione della pericolosità da frana in località Passo della Morte. Unpublished $\mathrm{PhD}$ thesis. University of Modena and Reggio Emilia, Italy.

Martinis B. (1985) - Il lago quaternario di Forni di Sotto (Alpi Carniche). Alto 67, 71-83.

Sinigardi G., Bossi G., Scuri A., Marcato G. \& Borgatti L. (2015) - Geological and numerical models as a tool to manage landslide risk: The Passo della Morte case study (UD, Italy). Rend. Online Soc. Geol. Ital. 34, 46-53.

VV.AA. (2010) - DAN3D Dynamic Analysis of Landslides in Three Dimensions (Beta Version 2). User's manual. Vancouver, Canada. 